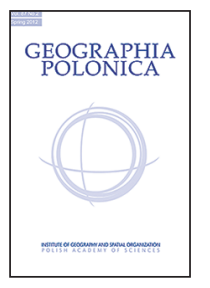 \\ INSTITUTE OF GEOGRAPHY AND SPATIAL ORGANIZATION \\ POLISH ACADEMY OF SCIENCES \\ www.igipz.pan.pl \\ www.geographiapolonica.pl
}

\title{
ECONOMIC CONTROL FUNCTIONS IN POLAND IN 2013
}

\section{Przemysław Śleszyński}

Institute of Geography and Spatial Organization

Polish Academy of Sciences

Twarda 51/55, 00-818 Warsaw: Poland

e-mail: psleszyn@twarda.pan.pl

\section{Abstract}

The map and the accompanying description present the variability of revenues and the spatial distribution of the corporate headquarters of the 2000 largest companies registered in Poland as of 2013, excluding banks. The study demonstrated a strong concentration of the decision-making and control functions in Warsaw. It found variability depending on the type of activity and ownership. The study also confirmed previous findings about economic management models and their links to the administrative and settlement hierarchy (Śleszyński 2002, 2007).

\section{Key words}

geography of enterprise - corporate geography - control function - decision function - economic power - enterprise - Poland

\section{Introduction}

In a market economy the location of a business has significant consequences. The location of an economic control function is linked with the following roles (Śleszyński 2002, 2007):

1. The economic role, the most complex of the three roles, determines the contribution to the local GDP and tax returns depending on whether a company has or does not have branch networks or other kinds of remote offices. Branch networks and other types of remote offices are typical of large service sector companies, especially in banking. Other aspects of the economic role involve the contribution to the overall level of investment and the multiplier effect, which in this case involves the pulling power that a large business exerts on other businesses, such 
as financial, legal, logistic and advisory services in a given area.

2. The social role includes two strictly interlinked groups, i.e. economic effects (such as the impact on the unemployment rate and the migration of highly skilled personnel) and reputation effects (heightened prestige of a town or region directly translated into such an effect as attractiveness to investors).

3. The political role, when a business becomes represented in the local authorities and gains real influence on the local administration and the management of the town or region.

The location of a company's headquarters and that of its actual place of business are not always one and the same. This is particularly true in companies with numerous branches, including especially those belonging to the financial sector (banking and insurance) and the service and commerce sector, but less those belonging to the manufacturing sector. This means that the location of the corporate headquarters is indicative more of the distribution of decision-making centres, i.e. of the control function, than of the actual location of the production resources. Therefore the distribution of corporate headquarters is indicative of the 'management space'.

In practice, economic control functions are present in nearly all settlements. Depending on its size and specialisation the geographical coverage of this function, and consequently its significance, varies. In most cases, the significance of a company is explicitly linked to its size measured by its financial power (i.e. revenues, profits, and investment), labour force, etc.

The earliest Polish studies on the distribution of enterprise management locations were carried out in the 1960s (Eberhardt \& Wróbel 1963; Eberhardt 1968, 1987) and covered spatial impacts and the distribution of corporate headquarters vs. branch networks in the trade sector. During that era, the location of corporate headquarters was a result of central planning, while various administrative agencies were normally controlled from a central location in the country's capital. The administrative function had a prime influence on urban creation. Guzik and Gwosdz (2000) report that in 1974 the industrial sector was managed from eight ministries and 74 of their subordinate organisations.

Research into the economic control function accelerated after the fall of communism and the transition to a market economy (Rakowski 1996; Wyżnikiewicz 1997; Guzik \& Gwosdz 2000; Nowosielska 2001; Wendt 2001; Śleszyński 2002a, 2006, 2007, 2014; Lijewski 2003; Rogacki 2006; Taylor \& Ciechański 2014, 2015), including targeting the global scale (Zioło 2006; Kilar 2014). These efforts of Polish geographers of industry are discussed by Domański (1997) and Śleszyński (2007).

\section{Data sources and methodology}

This analysis uses annual financial data on Polish companies published by the Rzeczpospolita daily. Its report "Lista 2000" (or "List 2000") (Rzeczpospolita in 2014) is based on the financial reports of companies, but excludes banks and public institutions, such as central and local administration. Nearly all of the companies included are bodies incorporated under Polish law and specifically the Code of Commercial Companies. The companies are ranked by their overall size of revenues from all their activities. In 2013, the list was topped by a company with 113.9 bn zloties in revenues (Polski Koncern Naftowy Orlen S.A.), while the bottom companies had 120.3 m zloties (Top-Farms Głubczyce sp. z o.o.).

The map and body of the text lists by corporate headquarters the revenues from the overall activity of these 2000 largest companies. The corporate headquarters were found in 521 different towns, including an overwhelming majority in Warsaw (482; Fig. 1). The revenues of the whole group totalled 1,732 trillion zloties and accounted for $50.2 \%$ of Poland's gross output.

The data were broken down in a number of ways. The primary breakdown followed the 
Statistical Classification of Economic Activities in the European Community (NACE) and its simplified version that aggregated industries into four major economic sectors: agriculture (section $A)$, industry $(B, C, D, E, F)$, less specialised services $(G, H, I, S, T)$ and highly specialised services (J, K, L, M, N, O, P, Q, $R, U)$. The subdivision of the services sector addressed its strong heterogeneity. None of the top 2000 Polish companies in the report represented sections: P, R, S, T, U. Additionally, an ownership breakdown was used: municipal-owned, state-owned, privatelyowned and foreign-owned.
To find distribution patterns in terms of the functional-settlement hierarchy, localities were divided into four categories:

- capital city (Warsaw);

- other metropolitan cities with a core with more than 500 thousand inhabitants (Gdańsk-Gdynia-Sopot, Poznań, Wrocław, Łódź, Katowice conurbation and Kraków) including 19 cities with company headquarters;

- other regional and subregional towns (holding powiat status in the Polish administrative breakdown), including 44 towns;

- other localities, including 458 towns and villages.

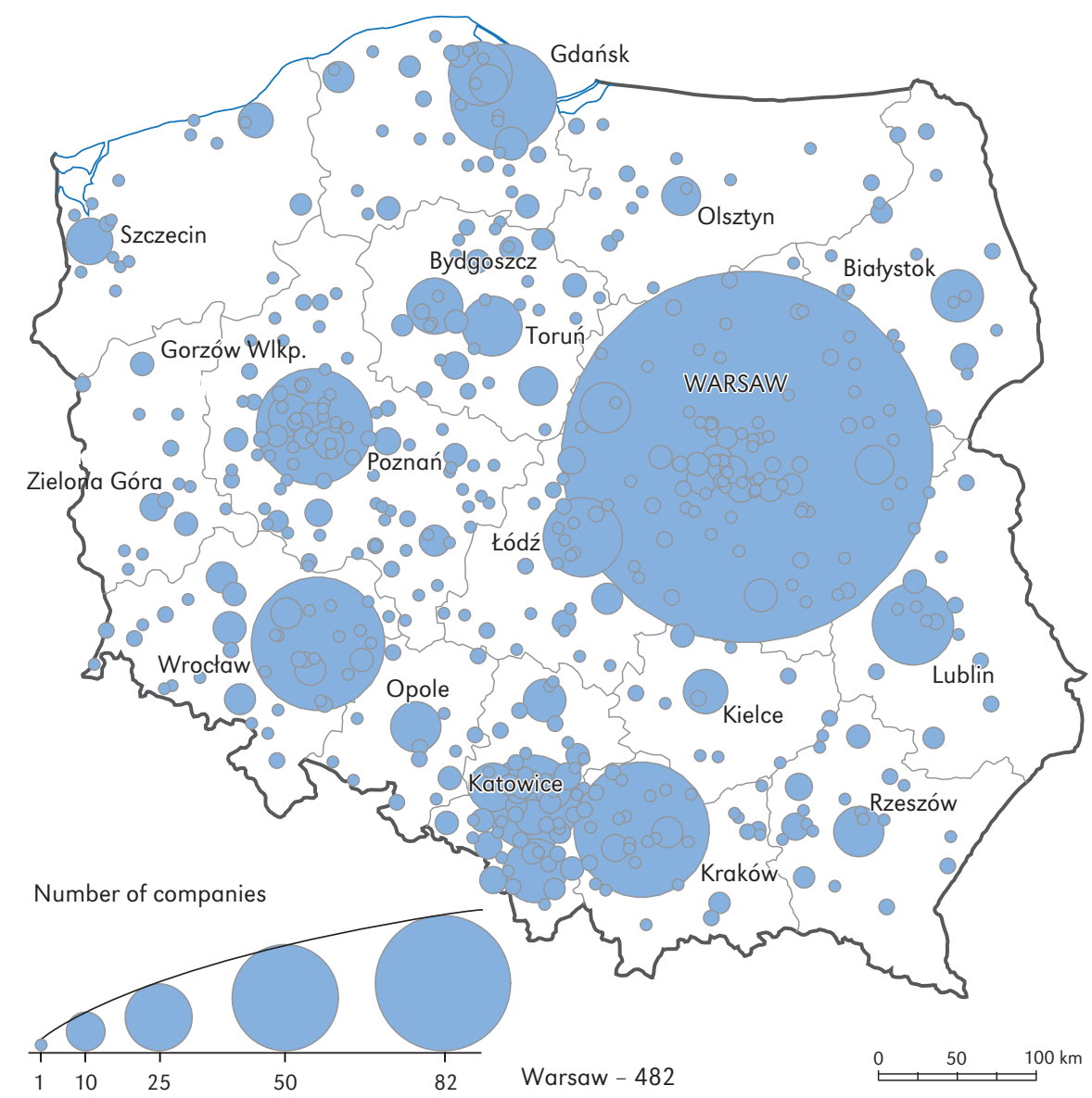

Figure 1. Distribution of companies on Rzeczpospolita's “Lista 2000" by corporate headquarters in 2013 Source: based on data shared by Rzeczpospolita in 2014 


\section{Results}

Table 1 summarises data on the concentration of company revenues in these localities. Companies located in Warsaw generated 501.2 trillion zloties in revenues, or $28.9 \%$ of the total revenues in the study. The top 10 cities concentrated $62.6 \%$ revenues and the top $100-88.6 \%$. This shows that economic power is concentrated in a relatively small number of localities including the capital city.

Table 1. Revenue concentration by localities in 2013

\begin{tabular}{|ll|r|r|}
\hline \multicolumn{1}{|c|}{ Top localities } & $\begin{array}{c}\text { Trillion } \\
\text { zloties }\end{array}$ & \% of total \\
\hline $1 \quad$ Warsaw & 501.2 & 28.9 \\
& $\begin{array}{l}\text { Warsaw and the } 9 \text { fol- } \\
\text { lowing localities by total } \\
\text { revenue }\end{array}$ & $1,084.1$ & 62.6 \\
$\begin{array}{l}\text { Warsaw and the } 99 \text { fol- } \\
\text { lowing localities by total } \\
\text { revenue }\end{array}$ & $1,534.6$ & 88.6 \\
\hline Total 513 localities & 1732.3 & 100.0 \\
\hline
\end{tabular}

Source: based on data shared by Rzeczpospolita in 2014
Table 2 lists these localities. After Warsaw the second city is Płock due to the location there of the corporate headquarters of Poland's largest company PKN Orlen (Polski Koncern Naftowy Orlen S.A.). This and 14 other "Lista 2000" companies controlled 138.8 trillion zloties in revenue. Subsequent towns and cities included: Poznań (63 companies, 90.6 trillion zloties), Gdańsk $(54,89.4)$, Kraków $(82,68.9)$, Katowice (44, 56.5), Wrocław $(81,50.1)$, Kostrzyn nad Odra $(2,33.7)$, Łódź $(32,29.7)$ and Lubin $(4,25.3)$. Most of these were large metropolitan cities (e.g. according to the ESPON classification), relatively strong industrial centres with some of Europe's and the world's largest manufacturing plants in their sectors (Lubin has the copper conglomerate KGHM while Kostrzyn nad Odra has the pulp and paper company ICT Poland).

At national level the largest proportion of revenues was accounted for by the sector of industry $(53.7 \%)$, followed by services $(45.7 \%)$ with a minor share of agriculture (0.6\%; mainly Lasy Państwowe, or State Forests National Forest Holding).

A more detailed breakdown of revenues by categories of localities is shown in

Table 2. Top 10 cities with largest total revenues in 2013

\begin{tabular}{|c|c|c|c|c|c|c|c|}
\hline \multirow[b]{2}{*}{ Locality } & \multirow[b]{2}{*}{$\begin{array}{c}\text { Number } \\
\text { of compa- } \\
\text { nies }\end{array}$} & \multirow[b]{2}{*}{$\begin{array}{l}\text { Total rev- } \\
\text { enues }\end{array}$} & \multicolumn{5}{|c|}{ Percentage share in sectors (sections of NACE classification) } \\
\hline & & & total & agriculture & $\begin{array}{l}\text { industry } \\
\text { (BCDEF) }\end{array}$ & $\begin{array}{c}\text { less } \\
\text { specialised } \\
\text { services } \\
\text { (GHI) }\end{array}$ & $\begin{array}{l}\text { highly } \\
\text { specialised } \\
\text { services } \\
\text { (JKL } \\
\text { NOPQ) }\end{array}$ \\
\hline Warsaw & 482 & 501.2 & 100.0 & 1.4 & 35.4 & 43.2 & 20.0 \\
\hline Płock & 15 & 138.8 & 100.0 & 0.0 & 85.3 & 14.7 & 0.0 \\
\hline Poznań & 63 & 90.6 & 100.0 & 1.3 & 40.1 & 47.2 & 11.4 \\
\hline Gdańsk & 54 & 89.4 & 100.0 & 0.0 & 62.2 & 33.9 & 4.0 \\
\hline Kraków & 82 & 68.9 & 100.0 & 0.0 & 34.3 & 59.2 & 6.5 \\
\hline Katowice & 44 & 56.5 & 100.0 & 0.0 & 70.2 & 28.8 & 1.0 \\
\hline Wrocław & 81 & 50.1 & 100.0 & 0.0 & 30.4 & 49.0 & 20.6 \\
\hline Kostrzyn nad Odra & 2 & 33.7 & 100.0 & 0.0 & 2.6 & 97.4 & 0.0 \\
\hline Łódź & 32 & 29.7 & 100.0 & 0.0 & 24.5 & 70.0 & 5.6 \\
\hline Lubin & 4 & 25.3 & 100.0 & 0.0 & 97.3 & 2.2 & 0.5 \\
\hline Total of Poland & 2,000 & $1,732.3$ & 100.0 & 0.6 & 53.7 & 36.0 & 9.7 \\
\hline
\end{tabular}

Source: based on data shared by Rzeczpospolita in 2014 
Figure 2. The location of company headquarters follows the functional-settlement hierarchy., The concentration of companies representing highly specialised services is the highest $(9.7 \%)$ at the top of the hierarchy, represented by the capital city of Warsaw. Localities at the bottom of the hierarchy concentrated the largest proportion of revenues from the industry sector (68.1\%). by the geographical location vis-à-vis Western Europe, including Germany, which after the shift to a market economy in 1989 became Poland's main trading partner. Indeed, the existing picture would suggest an influence of geographical proximity on the location of foreign investments (Domański 2000) in both existing companies and greenfield projects. Interestingly, this import-export link
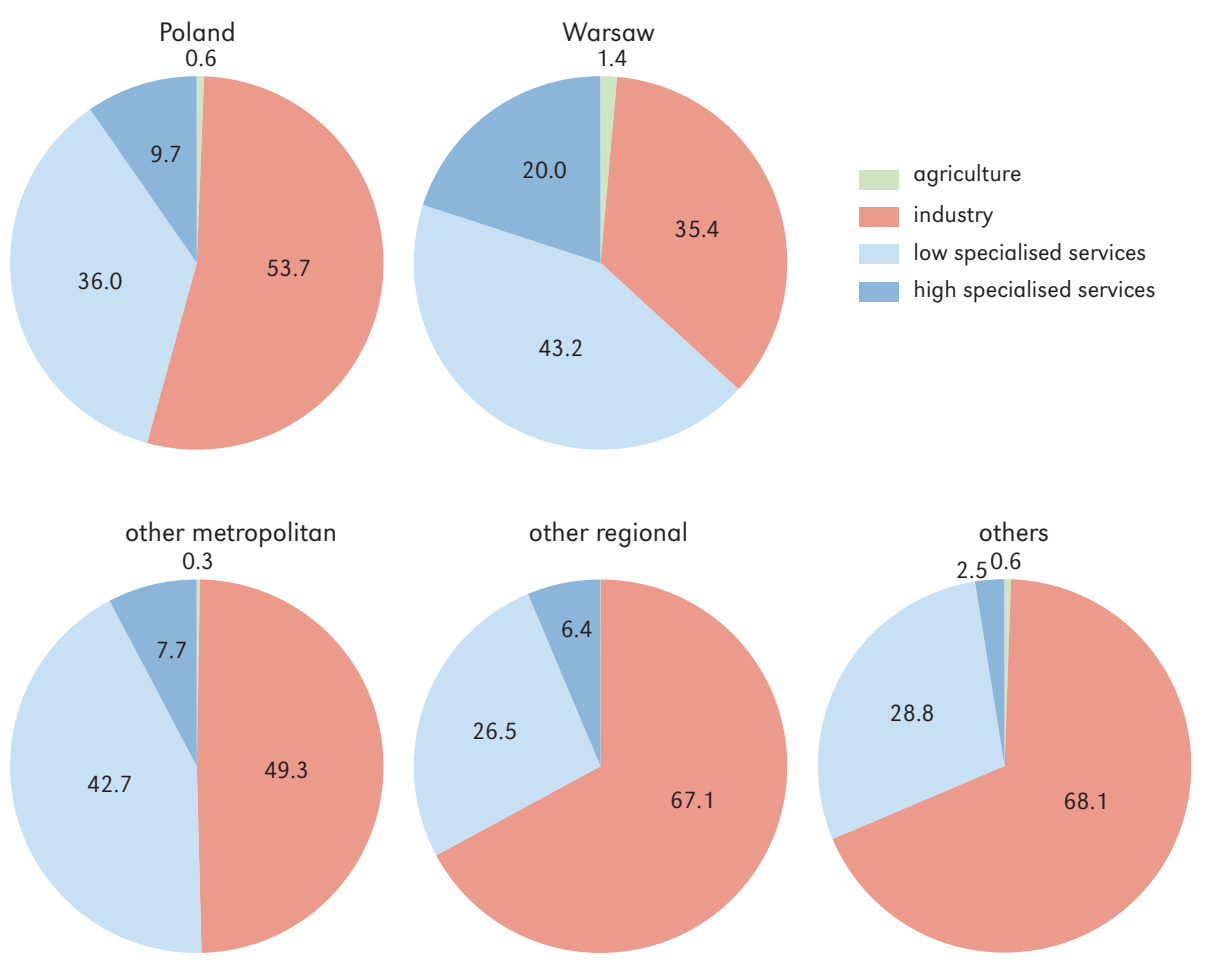

Figure 2. Sector structure of revenues by type of locality with company headquarters in 2013

Source: based on data shared by Rzeczpospolita in 2014

Interesting patterns were also found in the ownership structure. At national level foreign control accounted for the largest share of the total (43.3\%). This indicator was particularly dominant in a number of western Polish voivodeships (Lubuskie - 81.2\%, Wielkopolskie - 60.8\%, Zachodniopomorskie - 52.3\%). The opposite was true of provinces in the east of the country (Lubelskie - 9.9\%, Podlaskie $14,8 \%)$. It would be interesting to determine to what extent this pattern is determined is also influencing the development of other structures, including an adaptation of the higher-level road network (Śleszyński 2008).

\section{Discussion and conclusions}

The findings presented above are corroborated by other similar studies carried out first on a small sample of Poland's 500 largest companies (Śleszyński 2002) and then on a sample of 10,000 companies (Śleszyński 
Table 3. Ownership structure by the criteria of voivodeship and largest shareholder in 2013

\begin{tabular}{|c|c|c|c|c|c|}
\hline \multirow{2}{*}{ Voivodeship } & \multirow{2}{*}{$\begin{array}{l}\text { Total revenues } \\
\text { (trillion zloties) }\end{array}$} & \multicolumn{4}{|c|}{ Ownership } \\
\hline & & municipal & state & private & foreign \\
\hline Dolnoślqaskie & 121.1 & 0.6 & 4.1 & 53.8 & 41.4 \\
\hline Kujawsko-Pomorskie & 64.0 & 0.6 & 4.2 & 69.5 & 25.6 \\
\hline Lubelskie & 38.0 & 1.3 & 13.3 & 75.4 & 9.9 \\
\hline Lubuskie & 49.7 & 0.0 & 0.0 & 18.8 & 81.2 \\
\hline Łódzkie & 52.6 & 0.6 & 1.2 & 54.0 & 44.2 \\
\hline Małopolskie & 114.3 & 2.6 & 1.6 & 51.6 & 44.3 \\
\hline Mazowieckie & 711.1 & 0.4 & 17.3 & 37.7 & 44.5 \\
\hline Opolskie & 15.4 & 2.2 & 0.0 & 54.4 & 43.4 \\
\hline Podkarpackie & 28.5 & 0.0 & 0.7 & 72.7 & 26.7 \\
\hline Podlaskie & 22.5 & 1.1 & 0.0 & 84.1 & 14.8 \\
\hline Pomorskie & 118.4 & 0.5 & 58.6 & 20.1 & 20.7 \\
\hline Śląskie & 167.7 & 0.4 & 16.8 & 38.2 & 44.5 \\
\hline Świętokrzyskie & 21.6 & 0.0 & 0.0 & 58.5 & 41.5 \\
\hline Warmińsko-Mazurskie & 14.3 & 0.0 & 0.0 & 52.5 & 47.5 \\
\hline Wielkopolskie & 172.1 & 1.0 & 5.7 & 32.4 & 60.8 \\
\hline Zachodniopomorskie & 20.9 & 0.9 & 9.8 & 37.0 & 52.3 \\
\hline Poland total & $1,732.3$ & 0.7 & 14.3 & 41.7 & 43.3 \\
\hline
\end{tabular}

Source: based on data shared by Rzeczpospolita in 2014

2007). The study found considerable degrees of spatial concentration of the largest companies. The concentration in Warsaw had been inherited from the socialist system where the strong political and administrative function located in the capital city determined the location of economic management centres in the realities of a command economy. In future, a certain degree of deconcentration of the corporate headquarters of major companies measured both in terms of turnover and the number of entities may be expected. Even then, however, Warsaw will remain the single dominant centre.

The analysis of the location of Polish company headquarters has shown interesting dependencies in the country's urban and metropolitan networks. It transpires that the systems of spatial distribution of control functions in the economy (corporate headquarters) and of administration (centres of administrative power) only really overlap at the central level. The dominant role of Warsaw in the sense of economic management is indeed strongly linked with its administrative function. This was also a typical situation during the command economy period when central planning by central authorities was crucial. Therefore, the current distribution of company headquarters might be regarded as a legacy of the communist period. This would mean that the degree of decentralisation of the control function in the economy is a rough measure of the decentralisation of national administration in general.

Several voivodeship capitals (e.g. Zielona Góra, Gorzów Wielkopolski and Opole) play almost no role in economic management (among major companies), while role of some medium-sized towns is considerable (Płock, Bielsko-Biała).

Warsaw should be expected to survive as the leading centre of economic management. This will be due to the fact that despite the decentralisation and deconcentration trends observed in the Polish economy, the dominant role of the capital city will continue to have a pulling effect on the location decisions of new businesses. This would produce a spatial structure of the control 
function in the economy similar to those observed in countries such as France (Paris), the UK (London), Austria (Vienna) and Spain (Madrid). Findings about the spatial distribution of company head offices in Poland seem to be supported by similar studies elsewhere in post-communist Central Europe (Csomós \& Derruder 2014).

The patterns mentioned earlier and which are dependent on the accumulation of economic management can be distilled down to three hierarchical types (Fig. 3):

A. Dominant role of Warsaw (highly specialised services).

B. Dominant role of metropolitan and regional centres except Warsaw (less specialised services and/or manufacturing).

C. Dominant role of minor centres (including with manufacturing).
A general interpretation of this analysis could be that the location of company headquarters depends on how advanced is the activity pursued by the company. The more advanced the industry the higher up the network of national administrative hierarchy the location is.

Studies of the distribution of company headquarters may be helpful in explaining the processes of social and economic transformation, including economic decentralisation. They could also be applied in research on the development of new settlement structures, especially urban systems.

Editors' note:

Unless otherwise stated, the sources of tables and figures are the author's, on the basis of their own research.

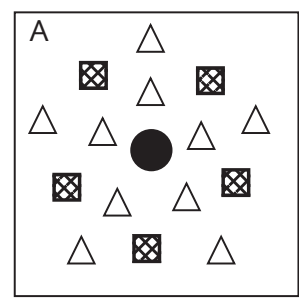

\section{settlement centres}

$\bigcirc$ capital

$\square$ other metropolitan/regional

$\triangle$ other

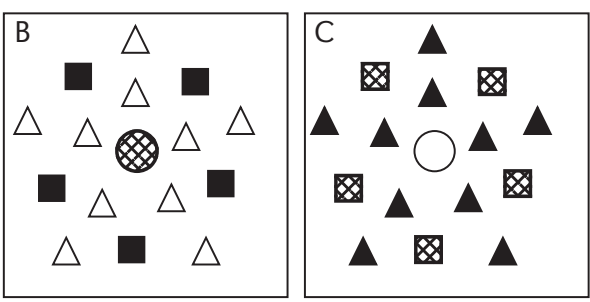

management of economy centres

dominant

complementary

$\square$ marginal

Figure 3. Hierarchical types of economic management in Poland

A - dominant role of Warsaw (highly specialised services), B - dominant role of metropolitan and regional centres except Warsaw (less specialised services, partially manufacturing activities) and C - dominant role of minor centres (partially manufacturing services).

Source: after Śleszyński 2002, modified

\section{References}

Csomós G., Derudder B., 2014. European cities as command and control centres, 2006-11. European Urban and Regional Studies, vol. 21, no. 3, pp. 345-352.
DomańSKI B., 1997. Geografia przedsiębiorstw - niedoceniany nurt badań w polskiej geografii ekonomicznej [in:] A. Jackowski (ed.), Geografia - Człowiek - Gospodarka. Profesorowi Bronisławowi Kortusowi w 70. rocznicę urodzin, Kraków: Instytut Geografii UJ, pp. 101-112. 
EberHARDt P., 1968. Wielkie miasta jako ośrodki koncentracji działalności gospodarczo-społecznej w Polsce. Biuletyn KPZK PAN, 47, Warszawa: Państwowe Wydawnictwo Naukowe.

Eberhardt P., 1986. Rejonizacja przedsiębiorstw zaopatrzenia, dystrybucji i handlu hurtowego w Polsce. Przegląd Geograficzny, vol. 58, vol. 4, pp. 703-733.

Eberhardt P., Wróbel A., 1963. Regiony handlu hurtowego w Polsce. Przegląd Geograficzny, vol. 35, no. 1, pp. 21-29.

GuzIK R., GwosDz K., 2000. The spatial concentration of control functions in Polish industry [in:] T. Marszał (ed.), Local economy and urban development in Poland, Łódź: Department of the Built Environment and Spatial Policy. University of Łódź, pp. 52-61.

KILAR W., 2015. Settlement concentration of economic potential represented by IT corporations. Geographia Polonica, vol. 88, no. 1, pp. 123-141.

LIJEWSKI T., 2003. Koncentracja ośrodków aktywności gospodarczej w Polsce w świetle list 500 firm. Przegląd Geograficzny, vol. 75, no. 3, pp. 433-447.

NowOSIELSKA E., 2001. Wielkie firmy usługowe w układzie nowych województw [in:] T. Czyż(ed.), Zróżnicowanie społeczno-gospodarcze w nowym układzie terytorialnym Polski, Biuletyn KPZK PAN, 197, Warszawa: Komitet Przestrzennego Zagospodarowania Kraju PAN, pp. 103-129.

RAKOWSKI W., 1996. Potencjał banków w układzie przestrzennym [in:] I. Fierla (ed.), Zmiany uwarunkowań lokalizacji przemysłu w Polsce. Część II, Monografie i Opracowania, 408, Warszawa: Szkoła Główna Handlowa, pp. 90-100.

RogaCKI H., 2006. Large industrial enterprises in Poland: Changes in the regional pattern. Quaestiones Geographicae, 25, pp. 53-59.

ŚleszYŃSKI P., 2002. Struktura i rozmieszczenie ośrodków zarzadzania w polskiej gospodarce w 2000 r. Przegląd Geograficzny, vol. 65, no. 2, pp. 199-228.

ŚLESZYŃSKI P., 2006. Przedsiębiorstwa w przestrzeni Warszawy. Atlas Warszawy, 9, Warszawa: Instytut Geografii i Przestrzennego Zagospodarowania PAN.
ŚLESZYŃSKI P., 2007. Gospodarcze funkcje kontrolne w przestrzeni Polski. Prace Geograficzne, 213, Warszawa: Instytut Geografii i Przestrzennego Zagospodarowania.

ŚLESZYŃSKI P., 2008. Ocena powiqzań gospodarczych i kapitałowych miedzy miastami [in:] K. Saganowski, M. Zagrzejewska-Fiedorowicz, P. Żuber (eds.), Ekspertyzy do Koncepcji Przestrzennego Zagospodarowania Kraju 20082033. Tom I, Warszawa: Ministerstwo Rozwoju Regionalnego, pp. 335-391.

ŚLESZYŃSKI P., 2014. Headquarters of large enterprises in the spatial structure of major Polish cities [in:] Z. Zioło, T. Rachwał (eds.), Contemporary issues in Polish industrial geography, Prace Komisji Geografii Przemysłu PTG, 25, Kraków: Wydawnictwo Naukowe Uniwersytetu Pedagogicznego, pp. 178-193.

TAYlor Z., CieChańSKI A., 2014. Funkcje kontrolne wielkich miast Polski w świetle bezpośrednich inwestycji zagranicznych $w$ transporcie. Przeglad Geograficzny, vol. 86, no. 2, pp. 141-170.

TAYLOR Z., CieChańSKI A., 2015. Control functions within large cities and foreign direct investment in the transport sector: Empirical evidence from Poland. Geographia Polonica, vol. 88, no. 4, pp. 557-573.

WendT J., 2001. Geografia władzy w Polsce. Gdańsk: Wydawnictwo Uniwersytetu Gdańskiego.

WYŻNIKIEWICZ B., 1997. Regionalne zróżnicowanie sity ekonomicznej (na podstawie "Listy 500" największych przedsiębiorstw Gazety Bankowej) [in:] G. Gorzelak (ed.), Przemiany polskiej przestrzeni, Studia Regionalne i Lokalne, 19 (52), Warszawa: Europejski Instytut Rozwoju Regionalnego i Lokalnego UW, pp. 205-228.

ZıoŁo Z., 2006. Zróżnicowanie światowej przestrzeni przemysłowej w świetle koncentracji siedzib zarzadów wiodacych korporacji [in:] Z. Zioło, T. Rachwał (eds.), Międzynarodowe uwarunkowania rozwoju przemysłu, Prace Komisji Geografii Przemysłu PTG, 8, Warszawa-Kraków: Wydawnictwo Naukowe Akademii Pedeagogicznej, pp. 9-26.
(C) Przemysław Śleszyński

(C) Geographia Polonica

(C) Institute of Geography and Spatial Organization

Polish Academy of Sciences - Warsaw • 2015
Article first received • August 2015 Article accepted • October 2015 


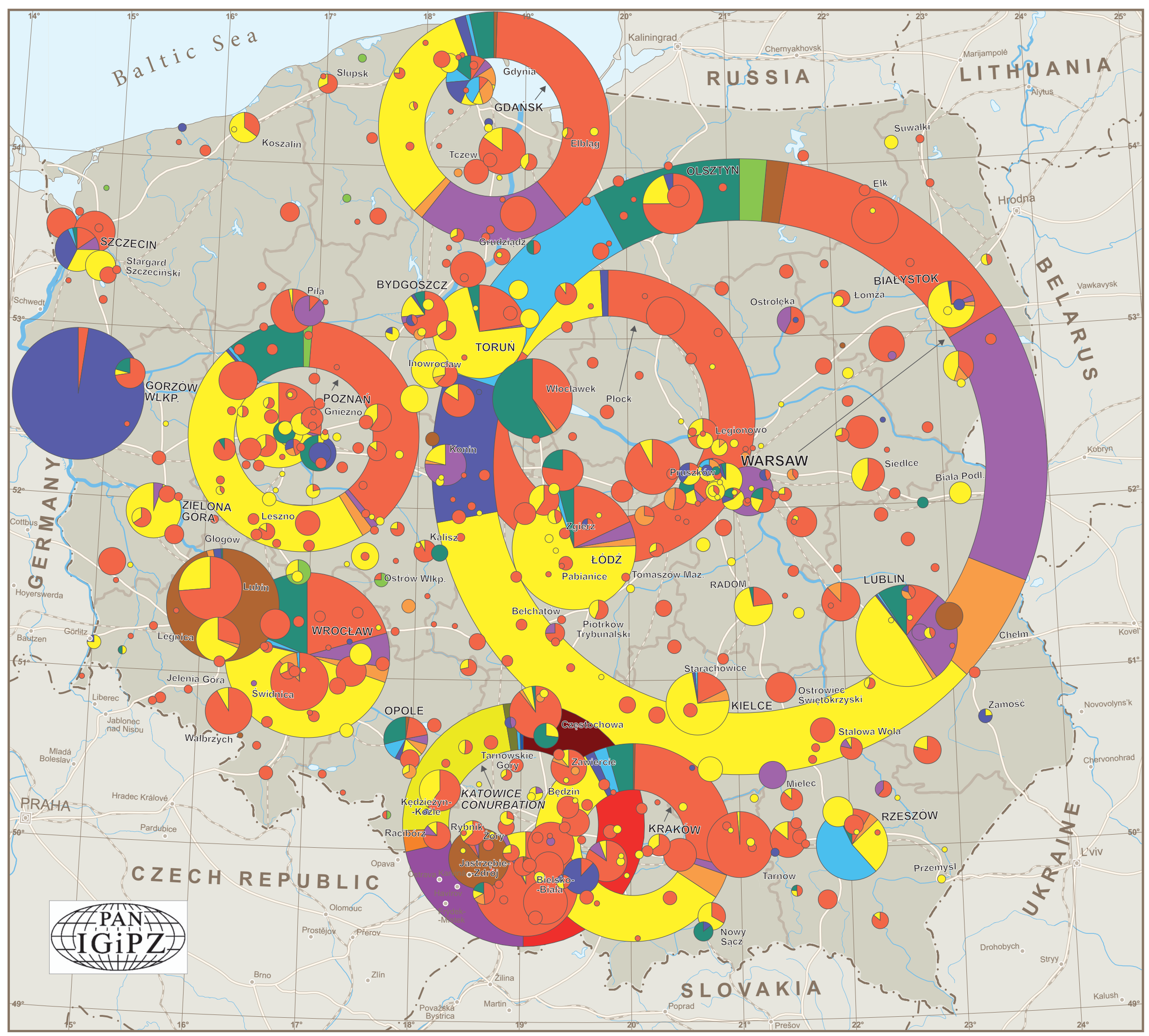

ECONOMIC CONTROL FUNCTIONS IN POLAND IN 2013

by Przemystaw Śleszyński

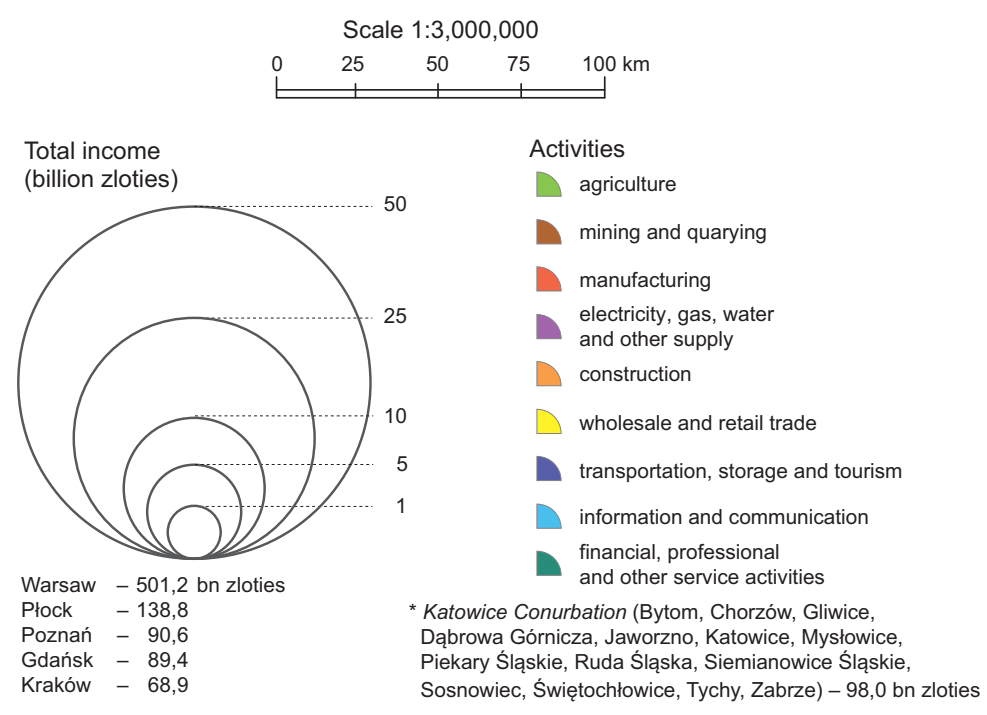

Ownership structure by voivodeship

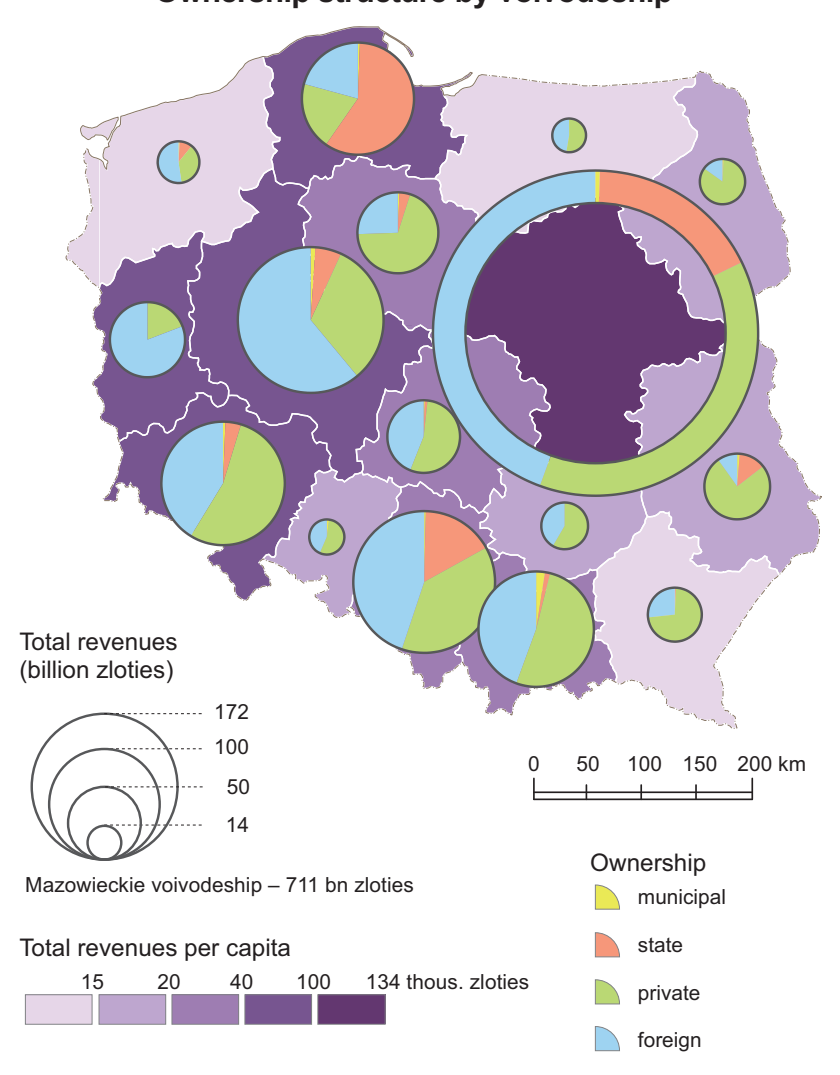

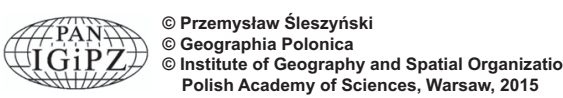




\section{REFEREES AND ADVISERS TO GEOGRAPHIA POLONICA 2015}

The Editors would like to extend their deepest thanks to all the Reviewers and Advisers for their invaluable contribution in reviewing the papers submitted to Geographia Polonica

JOHN BACHTLER

JAKUB BIJAK

MARTIN BOLTIŽIAR

JACEK BRDULAK

Anna Cenro

PAWEt CHURSKI

AndRZEJ CieśLIK

StANIStAW CIOK

Allan Cochrane

Peter Colwell

Giancarlo Cotella

GYÖRGY CSOMÓS

Matgorzata CZarneCKa

Bożena Degórska

Ben Derudder

JOHN DIXON

BolestaW DOMAŃSKI

Piotr EBerHARDT

MONIQUE FORT

BogdAN GĄDEK

Alon GelbMan

Magdalena GórCZYŃ́KKA

Elena GrigorieVA

BJÖRn GUNNARSON

JÁN HANUŠIN

Adelheid Holl

JURAJ HREŠKO

VLADIMÍR IRA

SigRUn KabisCH

RYSZARD J. KACZKA

DUŠAn KaRASKA

IGNACY KARDEL

Eva KISS

KAZIMIERZ KLIMEK

Jozef KobZA.

TOMASZ KOMORNICKI

Zoltán Kovács

AndRZEJ KowalczyK

JACEK KOZAK

Anna KozŁowsKa

JeRZY KOZYRA
University of Strathclyde, UK

University of Southampton, UK

University of Constantinus the Philosopher in Nitra, Slovakia

Warsaw School of Economics, Poland

University of Szczecin, Poland

Adam Mickiewicz University, Poznań, Poland

University of Warsaw, Poland

University of Wrocław, Poland

University of Toronto, Canada

University of Illinois, United States

Polytechnic University of Turin, Italy

University of Debrecen, Hungary

West Pomeranian University of Technology, Szczecin, Poland

Polish Academy of Sciences, Warsaw, Poland

Ghent University, Belgium

University of Arkansas, United States

Jagiellonian University, Kraków, Poland

Polish Academy of Sciences, Warsaw, Poland

Paris Diderot University, France

University of Silesia in Katowice, Poland

Kinneret College on the Sea of Galilee, Israel

Polish Academy of Sciences, Warsaw, Poland

Institute for Complex Analysis of Regional Problems, Birobidzhan, Russia

Stockholm University, Sweden

Slovak Academy of Sciences, Bratislava, Slovakia

Spanish National Research Council, Madrid, Spain

University of Constantinus the Philosopher in Nitra, Slovakia

Slovak Academy of Sciences, Bratislava, Slovakia

Department of Urban and Environmental Sociology, Leipzig, Germany

University of Silesia in Katowice, Poland

Horná Orava Protected Landscape Area, Namestovo, Slovakia

Division of Hydrology and Water ResourceS, Warsaw, Poland

Hungarian Academy of Sciences, Budapest, Hungary

University of Silesia in Katowice, Poland

University of Matej Bel, Banská Bystrica, Slovakia

Polish Academy of Sciences, Warsaw, Poland

Hungarian Academy of Sciences, Budapest, Hungary

University of Warsaw, Poland

Jagiellonian University, Kraków, Poland

Polish Academy of Sciences, Warsaw, Poland

Institute of Soil Science and Plant Cultivation, Puławy, Poland 
Kazimierz Krzemień

Stanislav Kucbel

StANISŁAW KUCHARZYK

Aleksander KuczabSKI

JÁN KUKLA

KadRI LeETMAA

ANDRZEJ LISOWSKI

ADAM ŁAJCZAK

Zoya MateEva

René Matlovič

Alessandro Messerl

Piotr Migoń

Urszula Myga-Piatek

Panagiotis Nastos

Michael NiedzielskI

TAdeusz NiedźWIedź

JÁN Novotný

JAN OTAHEL

Denise Pumain

TOMASZ RaChWAE

ZOFIA RĄCZKOWSKA

ANDRZEJ RICHLING

ELŻBIETA ROJAN

JÖRG RÖMBKE

AXEL SCHWERK

Olav Slaymaker

JERZY ŚLESZYŃSKI

Marek SobczyńSKI

Marcin StepNIAK

VÁclav TremL

Piotr Trzepacz

Melis Uzar

GRZEGORZ WeCŁAWOWICZ

Michael WoOds

TOMASZ ZALESKI

JACEK ZAUCHA

MIROSŁAW ŻELAZNY
Jagiellonian University, Kraków, Poland

Technical University in Zvolen, Slovakia

Bieszczady National Park, Ustrzyki Górne, Poland

Lviv Regional Institute of Public Administration, Ukraine

Institute of Forest Ecology, Zvolen, Slovakia

University of Tartu, Estonia

University of Warsaw, Poland

Pedagogical University of Kraków, Poland

Bulgarian Academy of Sciences, Sofia, Bulgaria

University of Presov, Slovakia

University of Florence, Italy

University of Wrocław, Poland

University of Silesia in Katowice, Poland

National and Kapodistrian University of Athens, Greece

Ohio State University, United States

University of Silesia in Katowice, Poland

Slovak Academy of Sciences, Bratislava, Slovakia

Slovak Academy of Sciences, Bratislava, Slovakia

Pantheon-Sorbonne University, Paris, France

Pedagogical University of Kraków, Poland

Polish Academy of Sciences, Kraków, Poland

University of Warsaw, Poland

University of Warsaw, Poland

Senckenberg Biodiversity and Climate Research Centre, Germany

Warsaw University of Life Sciences - SGGW, Poland

University of British Columbia, Vancouver, Canada

University of Warsaw, Poland

University of Łódź, Poland

Polish Academy of Sciences, Warsaw, Poland

Charles University in Prague, Czech Republic

Jagiellonian University, Kraków, Poland

Yıldız Technical University, Turkey

Polish Academy of Sciences, Warsaw, Poland

Aberystwyth University, UK

University of Agriculture in Kraków, Poland

Maritime Institute in Gdańsk, Poland

Jagiellonian University, Kraków, Poland 